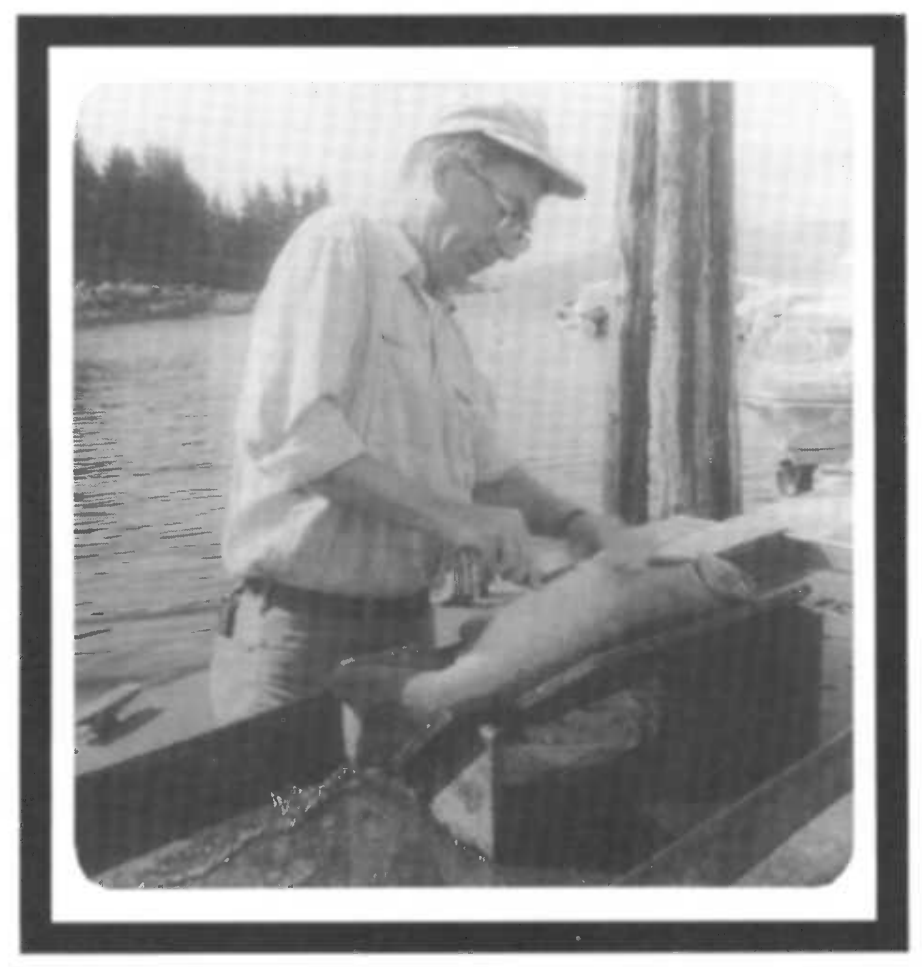

\title{
ROBERT STUCKENRATH, 1927-1994
}

Acerbic, abusive, brilliant, brusque, eclectic, exasperating, insightful, irritating, patient, patronizing, gentleman-these are but a few of the terms I have heard applied to Bob Stuckenrath over the 24year period that I knew him. Their contradictory diversity serves to capture, if not the essence, at least some of his many different facets as a man and scholar.

Bob came from a highly educated background. In another time, some would have said he had "learning" in the genes. His father was a lawyer and many others in his immediate and extended family had extensive college training. In such a milieu, and with his great store of native intelligence, it is not surprising that, from an early age, his own interests were broad and remarkably varied. Humorously, but ruefully, he would note that, except for Latin (which he learned as a law student), the linguistic talents that characterized his family did not extend to him. Indeed, in self-deprecating fashion, he described himself as " $\mathrm{p}^{* * *}$-poor" in languages. Accurate assessment or not, his career as a student followed many paths - which superficially may have appeared unrelated-as did his later professional life. Yet a pattern can be discerned beneath the seemingly disparate threads. He began his higher education at Swarthmore as a mechanical engineer and, in fact, worked briefly as a junior engineer for the Baldwin-Lima-Hamilton corporation. Shortly thereafter, he transferred to Allegheny College and changed his major to history. His long-abiding interests in the pre-Revolutionary War United States and in contemporary European history took formal shape during this period, and he graduated with a degree in history in 1952.

At this juncture, his education took another turn: perhaps influenced by his barrister father, Bob entered the University of Pennsylvania Law School, where he ultimately earned an LL.B. (later converted to a J.D.). Within the pursuit of his law degree, he not surprisingly enjoyed the historical ele- 
ments in title searching-"digging in the past" in a different way, he later called it-and he also became even quicker on his feet, expressing himself nimbly, logically, directly, and not uncommonly, devastatingly. Much of this "spin-off" from his legal education would serve him well and, indeed, distinguish him in his later years.

While at Penn Law School, he met his wife-to-be, Barbara, and through her was introduced to Elizabeth Ralph. Though he briefly served as a law clerk between 1955 and 1957, his legal career would end prematurely when his educational trajectory made its final shift. Uniting his historical interests with his not inconsiderable engineering talents, Bob served as a research assistant, research associate, and then research specialist in the Penn Radiocarbon Lab while completing his M.S. in Archaeology (1963) and his Ph.D. in Anthropology (1969). During his years at Penn, he had the opportunity to study within a milieu of dynamic scholars who included Robert Dyson, Carlton Coon, Loren Eiseley, Henry Fisher, J. Louis Giddings, James Pritchard, Linton Satterthwaite and both Kidders. Indeed, it was A. V. "Alfie" Kidder II who urged Bob to go to Debert, Nova Scotia, in 1963 with Douglas Byers. Widely regarded as a highly significant archaeological site from the time of its discovery, the careful excavation and dating program carried out for this fluted-point locality resulted in the recovery of a full suite of Paleo-Indian lithic artifacts firmly dated to $10,600 \mathrm{BP}$. Bob would return to Debert in 1964 and 1966, and also participate in a wide variety of other field projects, not just in archaeology but also in what now is usually called geoarchaeology. Following his M.A. project (on fluted-point chronologies in North America), Bob embarked on a study of sea-level changes in Chesapeake Bay. He would subsequently further develop and sustain an interest not only in the actors of antiquity but also in the stage upon which they performed. Indeed, from a very early point in his archaeological career he appreciated and championed a multidisciplinary approach to the systematic study of the human and natural record and their points of intersection. To his pride and credit, he never set aside or compromised that multi-field perspective.

During all of his formal academic training and fieldwork at Penn, he progressed in the Radiocarbon Lab from an "apprentice" scrubbing test tubes to a veritable master of his then still somewhat arcane craft. Indeed, his knowledge of all aspects of the dating process was encyclopedic-though he never deluded himself into believing that by being scientific, he actually practiced "science". For him, radiocarbon dating was no more and no less than a tool. It was not without reason that he referred to himself as Merlin, and when he finally had his own lab dubbed it Merlin's Lair.

At some point in 1967 or 1968, Betty Meggers and the late Clifford Evans heard Bob present a talk in Pullman, Washington, which ultimately led to Bob's appointment as Director of the Smithsonian Institution's Radiocarbon Laboratory, a position he would hold until 1986. Initially based in the basement of the "castle", then moved to the Radiation Biology Laboratory in Rockville, Maryland in 1970, the Smithsonian Radiocarbon Lab would become one of the leading archaeometric facilities in the world.

It was shortly after the establishment of the Rockville version of Merlin's den that I first met Bob. At that time, I was pursuing a postdoctoral project at the Smithsonian Institution that included, among other things, an attempt to unravel the evolution of basketry manufacture in prehistoric northern Mexico as reflected in Walt Taylor's Coahuila collections. With some trepidation, I approached Cliff Evans and Betty Meggers about having some of Taylor's perishables dated and was subsequently introduced to Bob. Many months and many odoriferous sandals, baskets, bags and even human coprolites later, I had a marvelous series of over 30 dates and, more importantly, had begun to appreciate Bob's incredible patience, attention to detail, and rigid insistence on the highest quality laboratory methods, from pretreatment through combustion, counting and ultimately the 
generation of a "date". I also quickly appreciated his equally rigorous insistence on the importance of well-defined stratigraphy, firm context and clear and unequivocal association relative to samples sent to him, and his utter contempt for archaeologists or other field workers whose data collection or documentation processes were not up to his standards. On many occasions, when asked about this putatively old site or that apparently anomalous date, or this archaeologist or that geologist, Bob would furrow his brow and bark "garbage in, garbage out!" Since the reliability of any date is only as good as its context, and its context only as good as its excavator, it is small wonder that when Bob weighed excavators on the scales of balance he found many wanting.

$\mathrm{He}$ frequently developed lifelong working relationships with those whose work he trusted, and it is not surprising that his circle of closest colleagues included a cadre of scholars well known for careful and meticulous field and lab practices. Interestingly, this group-which included geologists like Hal Borns, paleogeographers like Karl Butzer and archaeologists and geoarchaeologists like Bob Ackerman and Vance Haynes-all had a uniformly high opinion of Bob's work even when they disagreed with his professional views on certain subjects.

Nowhere was this more personally apparent to me than when he undertook in 1973-1974 the assay of the first of some 50 radiocarbon samples from Meadowcroft Rockshelter. In what was to become a nearly two-decade-long project, Bob produced a 12,000-16,000-yr occupational chronology, the very earliest phases of which have been hotly debated almost $a b$ initio. With Meadowcroft critics for whom he had little respect—or, sometimes, more accurately, little patience-he was indeed acerbic, abusive, brusque and caustic. But for others whose disagreements were well reasoned and carefully advanced, he had the greatest personal respect, whatever he might say (or, rarely, publish) in a moment of vexation.

My long experience with Bob during the Meadowcroft years led me (then Chair of Pitt's Anthropology Department and Director of the Cultural Resource Management Program) to offer Bob a "home" for his lab and a new position when the Smithsonian closed his facility for financial reasons in 1986. Once ensconced and fully operational in Pittsburgh, Bob continued to take on a myriad of archaeological, geological, geoarchaeological and paleoenvironmental dating projects from sites and localities all over the world. He would continue this pattern until and even after his lab was again closed for budgetary reasons in 1992. Indeed, shortly before his death, Bob had acted as a consultant to Exxon on possible damage to archaeological sites caused by the Valdez oil spill and, characteristically, brought his usual rigor to bear in that unfortunate situation.

Recounting the dozens of projects with which Bob was engaged throughout his long and productive career reflects the great breadth and depth of his scholarly interests but does not, in my mind, fully underscore his unique qualities as a nonpareil scientist or a man. Unfortunately, I can only touch on some of these.

His insistence on multiple dates (preferably in long stratigraphic series) was evident from his Debert dissertation days and would characterize his dating philosophy to the end. Whether it was Meadowcroft, the Lower Vaal River in South Africa, Baffin Island, coastal Maine or anywhere else, "more" was always better-if the excavator could be trusted. His willingness to experiment with new sample materials (from whale blubber to ostrich eggshells) or to refine methods appropriate to more "traditional" dating media like charcoal, paleosols or coprolites is also well documented in his career. In the ostrich egg "case study", another aspect of his character or personality was revealed when he and Karl Butzer collected a modern eggshell that Bob hoped to compare to archaeological specimens he was about to date. To preserve the shell for transport, they decided to hard-boil it, and while awaiting the results, became sufficiently engrossed in other matters to forget that they had not 
punctured the specimen before immersion. Blown back to reality by the exploding egg, they had plenty of time to consider their error while laughingly cleaning up the debris.

This incident reflects another side of Bob and one that many who did not know him well seldom saw-his great humor and wit. Even when he was caustic, he was elegantly caustic; and though he may have used humor as a weapon, he did it with dash, flair and inimitable style. Though he was not a misanthrope, I am sure Bob would have gotten on quite well with Jonathan Swift.

Characteristically, at the time of his death, Bob had a number of ongoing projects and obviously hoped to continue both his research and his lifelong "affair" with the outdoors, especially through the venue of fly-fishing. No one-least of all me-can summarize a life, a career and a person like Bob Stuckenrath. He was one of those very rare persons who, once met, was not easily forgotten or readily dismissed. Like his chosen namesake, the Merlin of Arthurian romance, some took him well, others took him badly, but no one took him lightly.

\section{ACKNOWLEDGMENTS}

The author wishes to acknowledge the kind assistance of Barbara Stuckenrath in assembling the details of Bob's career. This manuscript was typed by L. Hamblin and edited by D. Pedler at Mercyhurst College, Erie, Pennsylvania.

J. M. Adovasio

\section{SELECTED BIBLIOGRAPHY}

1960

Ralph, E. K. and Stuckenrath, R. Carbon-14 measurements of known-age samples. Nature 188 (4766): 185-187.

1962

Ralph, E. K. and Stuckenrath, R. University of Pennsylvania radiocarbon dates $V$. Radiocarbon 4: 144 159.

1963

Stuckenrath, R. University of Pennsylvania radiocarbon dates VI. Radiocarbon 5: 82-103.

1964

Stuckenrath, R. The Debert site: Early man in the Northeast. Expedition [Philadelphia] 7: 2-29.

1965

Stuckenrath, R. On the care and feeding of radiocarbon dates. Archaeology 18(4): 277-281.

Stuckenrath, R. and Ralph, E. K. University of Pennsylvania radiocarbon dates VIII. Radiocarbon 7: 187199.

Coe, W. R. and Stuckenrath, R. A review of La Venta, Tabasco, and its relevance to the Olmec problem. The Kroeber Anthropological Society Papers 13: $1-43$.

1966

Stuckenrath, R. Carbon-14 and the unwary archaeologist. In Chatters, R. M. and Olson, E. A., eds., Pro- ceedings. 6th International Conference on Radiocarbon and Tritium Dating. Pullman, Washington, Atomic Energy Commission: 304-317.

Stuckenrath, R., Coe, W. R. and Ralph, E. K. University of Pennsylvania radiocarbon dates IX. Radiocarbon 8: 348-385.

1967

Stuckenrath, R. The Debert site: Radiocarbon dating. Quaternaria 8: 75-80.

1969

Stuckenrath, R. and Lawn, B. University of Pennsylvania radiocarbon dates XI. Radiocarbon 11: 150-163.

1970

Stuckenrath, R. Book review of The Carbon-14 Dating of Iron. Science 168: 585.

Stuckenrath, R. and Mielke, J. E. Smithsonian Institution radiocarbon measurements VI. Radiocarbon 12: 193-204.

1972

Stuckenrath, R. and Mielke, J. E. Smithsonian Institution radiocarbon measurements VII. Radiocarbon 14: $401-412$.

Huang, T. C., Stanley, D. J. and Stuckenrath, R. Sedimentological evidence for current reversal at the Strait of Gibraltar. Marine Technology Journal 6: 25-33.

1973

Stuckenrath, R. and Mielke, J. E. Smithsonian Institution 
radiocarbon measurements VIII. Radiocarbon 15: 388-424.

Butzer, K. W., Fock, G. J. , Stuckenrath, R. and Zilch, A. Paleo-hydrology of Late Pleistocene lakes in the Alexandersfontein Pan, Kimberley, South Africa. Nature 243: 328-330.

Butzer, K. W., Helgren, D. M., Fock, G. J. and Stuckenrath, R. Alluvial terraces of the Lower Vaal River, South Africa: A reappraisal and reinvestigation. The Journal of Geology 81(3): 341-362.

1974

Rupke, N. A., Stanley, D. J. and Stuckenrath, R. Late Quaternary rates of abyssal mud deposition in the Western Mediterranean Sea. Marine Geology 16: M2-M16.

1975

Adovasio, J. M., Gunn, J. D., Donahue, J. and Stuckenrath, R. Excavations at Meadowcroft Rockshelter, 1973-1974. Pennsylvania Archaeologist 45: 130.

Andrews, J. T., Cararra, P., Stuckenrath, R. and King, J. Holocene environmental changes in the Alpine zone, Northern San Juan Mountains, Colorado: Evidence from bog stratigraphy and palynology. Quaternary Research 5: 173-197.

Davis, R. B., Bradstreet, T., Stuckenrath, R. and Borns, $H$. W. Vegetation and associated environments during the past 14,000 years near Moulton Pond, Maine. Quaternary Research 5: 435-465.

Macintyre, I. G., Blackwelder, B. W., Land, L. S. and Stuckenrath, R. North Carolina shelf-edge sandstone: Age, environment of origin, and relationship to pre-existing sea levels. Bulletin of the Geological Society of America 96: 1073-1078.

Stanley, D. J., Maldanado, A. and Stuckenrath, R. Strait of Sicily depositional rates and patterns, and possible reversal of current in the Late Quaternary. $\mathrm{Pa}$ leogeography, Paleo-climatology, and Paleoecology 18: 279-291.

1976

Dumond, D. E., Henn, D. and Stuckenrath, R. Archaeology and prehistory on the Alaskan Peninsula. Anthropological Papers of the University of Alaska 18: 17-29.

1977

Stuckenrath, R. Radiocarbon: Notes from Merlin's diary. In Newman, W. S. and Salwen, S., eds., Amerinds and Their Paleoenvironments in Northeastern North America. New York, New York Academy of Sciences: $181-188$.

Adovasio, J. M., Gunn, J., Donahue, J. and Stuckenrath, R. Meadowcroft Rockshelter: Retrospect 1977. Pennsylvania Archaeologist 42: 1-93.

Progress report on the Meadowcroft Rocksheltera 16,000 year chronicle. In Newman, W. S. and Salwen, S., eds., Amerinds and Their Paleoenviron- ments in Northeastern North America. New York, New York Academy of Sciences: 137-159.

Crowl, G. H. and Stuckenrath, R. Geological setting of the Shawnee-Minisink Paleoindian archaeological site. In Newman, W. S. and Salwen, S., eds., Amerinds and Their Paleoenvironments in Northeastern North America. New York, New York Academy of Sciences: 282-296.

1978

Adovasio, J. M., Gunn, J., Donahue, J. and Stuckenrath, R. Meadowcroft Rockshelter, 1977: An overview. American Antiquity 43: 632-651.

Hyland, F., Thompson, W. B. and Stuckenrath, R. Late Wisconsinan wood and other tree remains in the Presumpscot Formation, Portland, Maine. Maritime Sediments 14: 103-120.

Lighty, R. G., Macintyre, I. G. and Stuckenrath, R. Submerged Early Holocene barrier reef, southeast Florida Shelf. Nature 275: 59-60.

1979

Stuckenrath, R., Miller, G. H. and Andrews, J. T. Problems of radiocarbon dating of organic-rich sediments, Cumberland Peninsula, Baffin Island, N.WT. Arctic and Alpine Research 11: 109-120.

Ackerman, R., Hamilton, T. and Stuckenrath, R. Early culture complexes on the northern Northwest Coast. Canadian Journal of Archaeology 3: 195209.

Butzer, K. W., Fock, G. J., Scott, L. and Stuckenrath, R. Dating and context of rock engravings in southern Africa. Science 203: 1201-1214.

Butzer, K. W., Halgren, D., Stuckenrath, R. and Brucewicz, A. Late Cenozoic paleoclimates of the Gaap Escarpment, South Africa. Quaternary Research 11: 310-339.

Lighty, R. G., Macintyre, I. G. and Stuckenrath, R. Reply to Braithwaite, J. R., Holocene growth on the edge of the Florida Shelf. Nature 278: 281-282.

Reply to Goldberg, W. M., Shelf temperatures and reef growth on the Southeast Florida Coast. Nature 278: 669-670.

1980

Adovasio, J. M., Gunn, J., Donahue, J., Stuckenrath, R., Guilday, J. and Volman, K. Yes, Virginia, it really is that old; reply to Haynes and Mead. American Antiquity 45: 588-599.

Serkin, L., and Stuckenrath, R. The Port Washingtonian warm interval in the Northern Atlantic coastal plain Bulletin of the Geological Society of America 91: 332-336.

Stanley, D. J., Rehault, J. P. and Stuckenrath, R. Turbidlayer bypassing model: The Corsican trench, Northwestern Mediterranean. Marine Geology 37: 19-40.

1981

England, J., Bradley, R. S. and Stuckenrath, R. Multiple glaciations and marine transgressions, Western Ken- 
nedy Channel, N.W.T., Canada. Boreas 10: 71-89.

Stanley, D. J., Taylor, P. T., Sheng, M. and Stuckenrath,

R. Sohm Abyssal Plain: Evaluating Proximal Sediment Provenance. Smithsonian Contributions to the Marine Sciences 11. Washington, Smithsonian Institution Press: $48 \mathrm{p}$.

1982

Lighty, R. G., Macintyre, I. G. and Stuckenrath, R. Acropora Palmata reef framework: A reliable indicator of sea level in the Western Atlantic for the past 10,000 years. Coral Reefs 1: 125-130.

Macintyre, I. G., Burke, R. B. and Stuckenrath, R. Core holes in the outer fore reef off Carrie Bow Cay, Belize: A key to the Holocene history of the Belizean Barrier Reef complex. In Gomez, E. D., ed., The Reef and Man: Proceedings of the Fourth International Coral Reef Symposium. Quezon City, Marine Sciences Center, University of the Philippines.

Pewe, T., Rowan, D., Pewe, R. and Stuckenrath, R. Glacial and Periglacial Geology of Northwest Blomsletta Peninsula, Spitsbergen, Svalbard. Oslo, Norskpolarinstitutt: $32 \mathrm{p}$.

1983

Adovasio, J. M., Donahue, J., Guilday, J. E., Stuckenrath, R., Gunn, J. D. and Johnson, W. C. Meadowcroft Rockshelter and the peopling of the New World. In Masters, P. M. and Flemming, N. C., eds., Quaternary Coastlines and Marine Archaeology. Academic Press, London: 413-439.

Belknap, D. F., Kelley, J. T., Borns, H. W., Shipp, R. C., Jacobson, G. L. and Stuckenrath, R. Sea-level change curves for coastal Maine. Report to Nuclear Regulatory Commission, Crustal Warping Studies in Maine: $35 \mathrm{p}$.

Holliday, V. T., Johnson, E. and Stuckenrath, R. Radiocarbon ages from the Lubbock Lake site, 1950 1980: Framework for cultural and ecological change on the southern High Plains. Plains Anthropologist 28: 165-182.

Lighty, R. G., Macintyre, I. G. and Stuckenrath, R. Holocene sea-level curve for the Caribbean and tropical Western Atlantic based on coral growth of shallowwater Acropora palmata reef framework. EOS 64(52): 1086.

Macintyre, I. G., Raymond, B. and Stuckenrath, R. Recent History of a Fringing Reef, Bahia Salina del Sur, Vieques Island, Porto Rico. Atoll Research Bulletin 268. Smithsonian Institution, Washington, D.C.

1984

Adovasio, J. M., Donahue, J., Carlisle, R. C., Cushman, K., Stuckenrath, R. and Weigman, P. Meadowcroft Rockshelter and the Pleistocene/Holocene Transition in Southwestern Pennsylvania. In Genoways, H. H. and Dawson, M. R., eds., Contributions in Quaternary Vertebrate Paleontology: A Volume in
Memorial to John W. Guilday. Pittsburgh, Carnegie Museum of Natural History: 347-369.

Andrews, J. T., Kihl, R., Caine, T. N., Birkeland, M. Z., Litaor, P. W., Dellmonte, N. L. and Stuckenrath, R. Characteristics of lake sediments from Alpine and subalpine environments: Front Range, Colorado. Long-Term Ecological Research Report 6/84. Institute for Arctic and Alpine Research, Boulder, Colorado: $29 \mathrm{p}$.

Guilday, J. E., Cotter, J. F. P., Cundall, D., Evenson, E. B., Gatewood, J. B., Morgan, A.V., McCrady, A. D., Peteet, D. M., Stuckenrath, R. and Vanderwal, K. Paleoecology of an Early Pleistocene (Irvingtonian) cenote: Preliminary report on the Hanover Quarry No. 1 Fissure, Adams County, Pennsylvania. In C. Mahaney, ed., Correlation of Quaternary Chronologies. Norwich, Geo Books: 119-132.

Pfeiffer, J. E. and Stuckenrath, R. Radiometric dates from two cremation burial sites in southern New England. Bulletin of the Archaeological Society of Connecticut 52: 151-154.

Serkin, L., Padillo, G. A., Pedrin, S. A., Diaz, R. A., Moran, M. J. and Stuckenrath, R. Quaternary marine deposits, raised marine terraces, and tectonism in Baja California Sur, Mexico: A report on research in progress. In V. Malpica-Cruz, ed., Neotectonics and Sea-Level Variations in the Gulf of California Area: A Symposium. Mexico, Instituto de Geologia, Universidad Nacional Autonoma de Mexico: 319-340.

Stanley, D. J., Nelson, T. A. and Stuckenrath, R. Recent sedimentation on the New Jersey slope and rise. Science 226: 125-133.

1985

Stuckenrath, R., regional compiler and contributor. Thompson, W. B. and Borns, H. W., eds., Surficial Geologic Map of Maine. Augusta, Maine Geological Survey, Department of Conservation.

Macintyre, I. G., Multer, H. G., Zankl, M. L., Hubbard, D. K., Weiss, M. P. and Stuckenrath, R. Growth and depositional facies of a windward reef complex (Nonesuch Bay, Antigua, W. I.). In Proceedings of the Fifth International Coral Reef Congress. Moorea, French Polynesia, Antenne MuseumEPHE 6: 605-610.

1986

Anderson, R. S., Davis, R. B., Miller, N. G. and Stuckenrath, R. History of Late-and Post-Glacial vegetation and disturbance around Upper South Branch Pond, Northern Maine. Canadian Journal of Botany 64: 1977-1986.

Cotter, J. F. P., Ridge, J. C., Evenson, E. B., Serkin, L. and Stuckenrath, $\mathbf{R}$. The Wisconsin history of the Great Valley, Pennsylvania, and New Jersey, and the age of the "Terminal Moraine". New York State Museum Bulletin 145: 22-47.

Jorstad, T., East, T., Adovasio, J. M. and Stuckenrath, R. Paleosols and Prehistoric Populations in the High 
Plains. Geoarchaeology 1: 163-181.

Kite, J. S. and Stuckenrath, R. Postglacial history of the Upper St. John drainage basin. In Contributions to the Quaternary Geology of Northern Maine and Adjacent Canada. Maine Geological Survey Bulletin 37: 113-128.

Peterson, J. B., Hamilton, N. D., Putnam, D. E., Spiess, A. E., Stuckenrath, R., Thayer, C. A. and Wolford, J. A. The Piscataquis archaeological project: A Late Pleistocene and Holocene occupational sequence in Northern New England. Archaeology of Eastern North America 14: 1-18.

Rabassa, J., Heusser, C. and Stuckenrath, R. New data on Holocene sea transgression in the Beagle Channel: Tierra del Fuego, Argentina. Quaternary of South America and Antarctic Peninsula 4: 291-309.

1987

Belknap, D. F., Anderson, B. G., Anderson, R. S., Anderson, W. A., Borns, H. W., Jacobson, G. L., Kelley, J. T., Shipp, R. C., Smith, D. C., Stuckenrath, R., Thompson, W. B. and Tyler, D. A. Late Quaternary sea-level changes in Maine. In Nummedal, D., Pilkey, O. B. and Howards, J. D., eds., Sea-Level Fluctuations and Coastal Evclution. Society of Economic Paleontologists and Mineralogists Special Publication 41. Tulsa, Oklahoma, SEPM: 71-85.

Borns, H. W. and Stuckenrath, R. Deglaciation of the Hemnefjord, South Trondelag, Western Norway. Abstracts of the Geological Society of America.

Holloway, R. G., Raab, L. M. and Stuckenrath, R. Pollen analysis of Late-Holocene sediments from a Central Texas bog. The Texas Journal of Science 39: 71-79.

Kite, J. S. and Stuckenrath, R. Postglacial evolution of drainage in the middle and upper St. John River Basin, New Brunswick and Maine. Paleohydrological Changes in the Temperate Zone in the last 15,000 Years. Abstracts of Papers, XIII INQUA, Ottawa, Canada: 15-24.

1988

Heusser, C. J., Rabassa, J., Brandani, A. and Stuckenrath, R. Late Holocene vegetation of the Andean Araucaria region, Province of Neuquen, Argentina. Mountain Research and Development 8(1): 53-63.

1989

Adovasio, J. M., Donahue, J., Stuckenrath, R. and Carlisle, $R$. C. The Meadowcroft Rockshelter radiocarbon chronology 1975-1989: Some ruminations. The First World Summit Conference on the Peopling of the Americas, University of Maine, May 1989.

Kite, J. S., and Stuckenrath, R. Postglacial evolution of drainage in the middle and upper St. John River Basin, Maine and New Brunswick. Studies in Maine
Geology 6: 135-142.

Moss, M. L., Erlandson, J. M., and Stuckenrath, R. The antiquity of Tlingit settlement on Admiralty Island, Southeast Alaska. American Antiquity 54: 534-542.

Retelle, M. J., Bradley, R. D. and Stuckenrath, R. Relative sea level chronology determined from raised marine sediments and coastal isolation basins, Northeastern Ellesmere Island, Canada. Arctic and Alpine Research 21(2): 113-125.

Rogers, R. L., Kite, J. S. and Stuckenrath, R. Stratigraphy and geologic history of a low terrace on the Ohio River, Apple Grove, West Virginia. Abstracts of the Geological Society of America.

1990

Stuckenrath, R. Time/depth anomalies in Maine sediments: Wha' hoppin? Poster session, American Quaternary Association, University of Waterloo, Ontario.

Heckenberger, M. J., Peterson, J. B., Basa, L. A., Cowie, E. R., Spiess, A. E. and Stuckenrath, R. Early Woodland Period mortuary ceremonialism in the Far Northeast: A view from the Boucher Cemetery. Archaeology of Eastern North America 18: 109144.

Lowell, T. V., Savage, K. M., Brockman, C. S. and Stuckenrath, R. Radiocarbon analyses from Cincinnati, Ohio, and their implications for Glacial stratigraphic interpretations. Quaternary Research 34: 1-11.

Lowell, T. V. and Stuckenrath, R. Late Wisconsin advance and retreat pattern in the Miami Sublobe, Laurentide Ice Sheet. International Glaciological Society, Symposium of Ice and Climate, Seattle, 1989.

Moss, M. L., Erlandson, J. M. and Stuckenrath, R. Wood stake weirs and salmon fishing on the Northwest Coast: Evidence from Southeast Alaska. Canadian Journal of Archaeology 14: 143-158.

1992

Anderson, R. S., Jacobson, G. L., Davis, R. B. and Stuckenrath, R. Gould Pond, Maine: Late Glacial transitions from marine to upland environments. Boreas 21: 359-371.

Kite, J. S., Rogers, R. L. and Stuckenrath, R. Cataclysmic Late Wisconsin floods in the Upper Ohio Valley. Abstracts of the Geological Society of America.

Watters, D. R., Donahue, J. and Stuckenrath, R. Paleoshorelines and the prehistory of Barbuda, West Indies. In L. L. Johnson, ed., Paleoshorelines and Prehistory: An Investigation of Method. Boca Raton, Florida, CRC Press: 15-52. 